\title{
Melkein kohti, ihan lähellä, melko keskellä
}

\author{
Mitä astemääritteet kertovat spatiaalisten grammien semantiikasta?
}

\section{Johdanto}

Astemääritteiksi kutsutaan erilaisia ominaisuuden astetta kuvaavia etumääritteitä (ISK, määritelmät). Astemääritteet voivat määrittää adjektiiveja (erittäin kaunis, ihan ruma), adverbeja (hyvin nopeasti) sekä eräitä adpositioita (aivan kirkon vieressä, melkein päin seinää). Tässä artikkelissa tarkastelen astemääritteiden ja kolmentyyppisten spatiaalisten grammien eli monifunktioisten kieliopillisten sanojen (ks. Svorou 1994, 32-35) yhteisesiintymisen mahdollisuuksia. Tarkasteltavat grammiryhmät ovat a) topologiset grammit (luona, lähellä, kaukana), b) suuntaa ilmaisevat grammit (kohti, ohi) ja c) tarkentavat grammit (keskellä, kohdalla). Astemääritteet jaan Paradisin (2001) tapaan kahteen pääryhmään: skalaarisesti avoimiin (melko, hyvin, erittäin) ja skalaarisesti sulkeisiin (melkein, täysin, aivan). Paradisin mukaan edelliset määrittävät yleensä skalaarisessa mielessä rajaamatonta ominaisuutta ilmaisevia adjektiiveja (vähän ruma, hyvin kaunis, erittäin hyvä), jälkimmäiset taas rajallista ominaisuutta ilmaisevia (melkein tyhjä, ihan täysi, aivan tosi). Varsinaisten astemääritteiden lisäksi esitän huomioita myös eräiden grammien yhteydessä mahdollisista matkan ja etäisyyden ilmauksista (kaksi metriä) sekä kvanttoriadverbeista (paljon). Pohdin, millaista skalaarisuutta kunkin grammiryhmän yhteydessä voidaan ilmaista ja mitä astemääritteiden ja grammien myötäesiintymisen mahdollisuudet ja yhteismerkitykset kertovat kummankin ilmaustyypin semantiikasta.

1 Tämän tutkimuksen on rahoittanut Suomen Akatemia (hanke 285739). Kiitän Krista Teeri-Niknammoghadamia sekä kahta Sananjalan nimetöntä arvioitsijaa hyödyllisistä ja arvokkaista kommenteista käsikirjoituksen aiempaan versioon. 


\subsection{Grammit ja skalaarisuus}

Monifunktioiset kieliopilliset sanat eli grammit voivat suomessa toimia adpositioina (Juoksin metsän läpi), itsenäisinä adverbeina (Sadetakki päästää vettä läpi) tai verbiin liittyvinä partikkeleina (Käy nuo paperit läpi). Käytän seuraavassa grammi-termiä kaikista adpositioina käytettävistä sanoista, myös sellaisista, joilla ei adpositiokäytön lisäksi ole muita kieliopillisia tehtäviä. Kognitiivisen kieliopin (esim. Langacker 2008) termein grammit ilmaisevat relaatioita eli suhteita, joiden pääosallistujat ovat muuttuja eli suhteutettava ja kiintopiste eli suhteutuskohta. Tärkeä käsite on myös hakualue eli se alue, jolle grammi rajaa muuttujan sijainnin. Esimerkiksi luona on grammi, joka ilmaisee muuttujan sijaintia kiintopisteen lähistöllä täsmentämättä, millä puolella kiintopistettä muuttuja sijaitsee. Hakualueen voi tällöin katsoa ympäröivän kiintopistettä sen joka puolelta. Hakualueen laajuus ja muuttujan sallittu etäisyys kiintopisteestä ovat aina suhteellisia, ja grammisanan käytön hyväksyttävyyteen vaikuttaa esimerkiksi muuttujan ja kiintopisteen koko.

Merkitykseltään läheistenkin grammien hakualueet saattavat perustua erilaisiin käsitteistyksiin eli kielenkäyttäjän tarkoitetilanteesta tekemiin tulkintoihin tilanteen kielentämiseksi. Edellä esittämäni pelkistetty luona-grammin merkityksen luonnehdinta tuntuisi ensi silmäykseltä sopivan myös sille semanttisesti läheiseen lähellä-grammiin (Kioski on kirkon luona kirkon lähellä). Molemmat ilmaisevat muuttujan sijaintia kiintopisteen lähistöllä suhteuttamatta sijaintia kiintopisteen omaan orientaatioon: ne eivät kerro esimerkiksi sitä, sijaitseeko muuttuja kiintopisteen edessä, takana vai vieressä. Molemmilla on myös suuntaiset vastineet (lähelle ja läheltä sekä luo[kse] ja luota), jotka ilmaisevat muuttujan siirtymistä hakualueelle tai sieltä pois. Grammien olennainen ero on kuitenkin siinä, että vain lähellä on Talmyn (2017, 315-316) termein skalaarinen grammi (ks. myös Haukioja 1998, 225-226). Tämä tarkoittaa, että sen kuvaama relaatio vallitsee hakualueen eri osissa erivahvuisena. Skalaarisuutta voidaan ilmaista astemääritteiden avulla: esimerkiksi melko lähellä ja erittäin lähellä kiintopistettä sijaitsevat muuttujat toteuttavat grammin ilmaiseman relaation eriasteisesti. Grammi luona taas ei kelpuuta mainittuja astemääritteitä: * melko erittäin luona.

Talmyn (2017) terminologian mukaan lähellä on skalaarisuudeltaan keskihakuinen grammi, sillä se esittää relaation vahvistuvan sitä mukaa kuin muuttujan ja kiintopisteen välimatka supistuu (melko lähellä erittäin lähellä). Keskihakuisuuden vastakohta on keskipakoisuus, josta esimerkiksi sopii grammi kaukana. Sen skalaarisuus vahvistuu muuttujan ja kiintopisteen välimatkan kasvaessa (melko kaukana erittäin kaukana). Talmy (mt., 315-316) liittää grammien skalaarisuuden fiktiiviseen liikkeeseen, jolla yleisesti tarkoitetaan staattisen tilanteen kielentämistä liikettä tai muuta muutosta merkitsevillä kielenaineksilla (Ykköstie menee Turusta Helsinkiin). Hän katsoo, että astemääritteen ja grammin yhdistelmän (esimerkiksi englannin very near 'hyvin lähellä) skalaarisesti ilmaisema sijainti voidaan ajatella muuttujan fiktiiviseksi liikkeeksi olinpaikkaansa. 
Talmyn mukaan keskihakuinen grammi esittää fiktiivisen liikkeen suuntautuvan kohti kiintopistettä, keskipakoinen grammi taas kiintopisteestä poispäin.

Astemääritteiden lisäksi skalaarisuutta voidaan ilmaista vertailumuodoilla lähempänä, kauempana, lähimpänä ja kauimpana. Lähellä-grammin skalaarisuus ilmenee myös siinä, että sen hakualueella ei ole selkeää ulkorajaa (ks. Haukioja 1998, 222). Raja on sumea ja ilmaistu relaatio pikemminkin suhteellinen kuin absoluuttinen. Esimerkiksi New York on lähempänä Helsinkiä kuin Los Angeles, vaikka kummankaan amerikkalaiskaupungin tuskin voi sanoa sijaitsevan Helsingin lähellä saati sen luona. Grammi luona ilmaiseekin selkeämmin rajautuvan hakualueen, jolla joko sijaitaan tai ei sijaita, eikä grammilla ole vertailumuotoja. Luona ei siten ole ainakaan samassa mielessä skalaarinen kuin lähellä, jonka merkityksessä korostuu suhteellinen etäisyys ja sen arviointi.

Myös luona sallii kuitenkin eräitä astemääritteitä, joista osa on yhteisiä lähellä-grammin kanssa. Tällainen on ainakin astemäärite ihan (Raitiovaunu on nyt ihan kirkon luona lähellä). Lisäksi ainakin liiketilanteiden kuvauksissa luona voi saada astemääritteet melkein ja täsmälleen, sillä liiketilanteissa on kyse muuttuvista etäisyyksistä, joita astemääritteet sitten täsmentävät (Raitiovaunu on nyt melkein täsmälleen kirkon luona).

Erot liittyvät myös grammien kielioppiin. Kieliopillisesti luona on aina genetiivitäydennyksen saava postpositio, lähellä taas preposition ja postposition tehtävien välillä vaihteleva bipositio, joka lisäksi kelpuuttaa sekä partitiivimuotoisen että (postpositiona) genetiivimuotoisen täydennyksen: lähellä kirkkoa, kirkkoa lähellä; kirkon lähellä. Toisin kuin luona, lähellä voi esiintyä myös ilman täydennystä adverbina (Kirkko on lähellä *luona). Sen komparatiivi- ja superlatiivimuodot lähempänä ja lähimpänä toimivat adpositioina vain partitiivitäydennyksen kera (lähempänä kirkkoa, lähimpänä kirkkoa, mutta ${ }^{\star} k i r k o n$ lähempänä, ${ }^{\star} k i r k o n$ lähimpänä). Tämä lähellä-grammin kieliopillinen moninaisuus mahdollistaa osaltaan sen, että hyvin erilaiset astemääritteet voivat esiintyä sen kanssa. Partitiivitäydennyksen genetiiviä väljempi suhde grammiin sallii astemääritteen sijoittumisen välittömästi grammin edelle silloinkin, kun grammia käytetään postpositiona (Kirkko näkyy jo tuolla, ja kotini on sitä aivan lähellä). Tällöin voi ajatella, että astemäärite liittyy pelkkään grammiin, ei koko adpositiolausekkeeseen. (Ks. ISK $₫ 692, \S 699, \S 703$.)

\subsection{Astemääritteiden ryhmittelyä}

Astemääritteet on ISK:n (\$657) kattotermi monenlaisille adjektiivien ja adverbien määritteille. Ryhmään kuuluvat adverbit niin, näin ja noin (näiden tehtävistä ks. Posio 2019), paljoutta ilmaisevat vähän, hiukan ja kovasti, sekä erilaiset intensiteettisanat. Viimeksi mainittuihin kuuluvat intensiteettipartikkelit, kuten aika, erittäin, hyvin, melko, vahvistussanoina esiintyvät genetiivimuodot, kuten erikoisen, hirveän, kohtalaisen, sekä ryhmä "muita", esimerkiksi todella, tosi, liian (ISK $\$ 664$ ).

Kaikkia edellä mainittuja ilmauksia yhdistää se, että niiden avulla "ominaisuuden asteen voi esittää olevan normaalia tai odotuksenmukaista korkeampi tai alhaisempi" (ISK $\$ 615$ ). Ominaisuus asemoidaan tällöin avoimelle skaalalle, jolla ei ole selvää ylä- tai alarajaa (Paradis 2001; ks. myös Orpana 1988, 67). Tästä syystä kutsun kaikkia mainittuja 
avoimen skaalan astemääritteiksi. Koska ryhmä on laaja, valitsen systemaattiseen tarkasteluun ilmaukset vähän, melko, hyvin ja erittäin, jotka tässä järjestyksessä asettuvat jatkumolle skalaarisesti alhaisimmasta korkeimpaan.

Lisäksi tarkastelen sulkeisen skaalan astemääritteitä. Sulkeisella skaalalla on alkuja loppuraja tai ainakin jompikumpi (ks. Kennedy ja McNally 2005). Sulkeisen skaalan astemääritteitä erottuu useita alatyyppejä. Niihin kuuluvat ensinnäkin täyteyden astemääritteet kuten täysin (ja sen vastapari osittain). Adjektiivia määrittäessään ne "ilmaisevat, missä määrin ominaisuus pätee puheena olevaan entiteettiin: kokonaan vai osittain" (ISK \$ 615). Adjektiiveista ne määrittävät yleensä sellaisia, jotka eivät komparoidu eivätkä esiinny (normaalikäytössä) intensiteettimääritteiden kera mutta ilmaisevat kuitenkin "ominaisuutta, jonka rajat on mahdollista saavuttaa", kuten tyhjä, täysi, samanlainen, (jonkin) kaltainen. Täyteyden astemääritteitä semanttisesti lähellä ovat rajaavat astemääritteet aivan ja ihan. Ne määrittävät adjektiiveja, joiden ilmaisemalla ominaisuudella on raja-arvo: ihan kauhea kampaus, aivan lyhyt juna (aivan-astemääritteen käyttäytymisestä tekstiaineistossa ks. Jantunen 2004). Approksimatiiviset astemääritteet (termistä ks. Radden ja Dirven 2007, 118) melkein ja lähes puolestaan tarkoittavat, että kuvailtava tarkoite on lähellä ominaisuuden alkurajaa, muttei aivan saavuta tätä: Lasisi on vielä lähes täysi, Tontti on melkein arvoton. Sulkeisen skaalan astemääritteisiin luen myös eräät likimääräisyyden ja täsmällisyyden adverbit (ISK $₫$ 661). Tällaisia ovat suunnilleen, tarkalleen ja täsmälleen. Ne eivät muista sulkeisen skaalan astemääritteistä poiketen suhteudu skaalan maksimi- tai minimiarvoon vaan määrittävät skaalalle asettuvaa täsmällistä arvoa, jota ne joko sumentavat (suunnilleen 30-vuotias) tai tarkentavat (tarkalleen viisikiloinen). Näitä kutsun tarkentaviksi astemääritteiksi.

Sulkeisen skaalan astemääritteiden alaryhmiä on syytä tarkastella erikseen, sillä niiden tehtävät ovat keskenään erilaisia. Niistä monikäyttöisimpiä ovat rajaavat aivan ja ihan, joiden päätehtävä on ilmaista ääriarvoa sulkeiseksi ymmärretyllä skaalalla, esimerkiksi Astiat ovat ihan puhtaita, Oopperailta oli aivan täydellinen. Ne sopivat kuitenkin joskus myös avointa skaalaa kuvaavien adjektiivien määritteiksi: Kirja on ihan hyvä. Tällaisten adjektiivien ja niiden antonyymiparikkien välillä vallitsee joskus epäsymmetria: kielteiseksi ymmärrettävän tai vähäistä määrää ilmaisevan parikin määritteinä aivan ja ihan ilmaisevat maksimaalista astetta, positiivisen tai suurehkoa määrää ilmaisevan parikin yhteydessä taas ei-maksimaalista astetta. Esimerkiksi ihan ruma ilmaisee 'rumuuden' maksimaalista astetta sulkeisella skaalalla (ja vastaavasti erittäin ruma avoimella skaalalla), mutta ihan kaunis tarkoittaa vain 'kohtalaisen' tai 'riittävän' kaunista ja siten 'kauneuden' matalampaa astetta kuin avoimen skaalan erittäin kaunis. Englannin quiteastemääritteellä on samalla tavoin vaihtelevia käyttöjä, ja sitä onkin luonnehdittu sekä vahvistavaksi että lieventäväksi astemääritteeksi (ks. Paradis 1997, 18 ja hänen mainitsemansa lähteet). 


\section{Grammien ja astemääritteiden yhteisesiintymisen mahdollisuudet}

Tarkastelen seuraavaksi kolmea spatiaalista grammiryhmää ja erilaisten astemääritteiden esiintymismahdollisuuksia näihin kuuluvien grammien kanssa. Tarkastelu perustuu pääasiassa tutkijan kielitajun käyttöön ${ }^{2}$ tavoiteilmausten muotoilussa ja niiden merkityksen sekä kielenmukaisuuden arvioinnissa. Olen käynyt systemaattisesti läpi kaikki tarkasteltavien grammien ja astemääritteiden periaatteessa mahdolliset yhdistelmät sekä arvioinut niiden kielenmukaisuutta ja merkitystä. Rajatapauksista olen hakenut esiintymiä Googlehakukoneella. Jonkin ilmaustyypin yksittäisiin esiintymiin internetissä tulee kuitenkin suhtautua evidenssinä varovaisesti. Vaikka esiintymien olemassaolo saattaakin heijastella puhujien kieli-intuitioiden vaihtelua, ne saattavat olla myös pelkkiä lipsahduksia tai tietoista kielellistä leikittelyä. Aineistoon perustuva tutkimus edellyttäisikin laajaa, systemaattisesti koottua otosta.

Grammien ja astemääritteiden semantiikkaa havainnollistan kognitiivisen kieliopin hengessä laadituilla kuvioilla. Kuviot on tarkoitettu juuri havainnollistuksiksi eikä esimerkiksi eksplisiittisiksi formaalistuksiksi (kuvioiden käytöstä ja asemasta kognitiivisessa kieliopissa ks. Langacker 2008, 9-12).

Astemääritteet jaan luvussa 2 esittämääni tapaan kahteen pääryhmään: avoimen skaalan ja sulkeisen skaalan astemääritteisiin. Tarkastelen kunkin grammiryhmän yhteydessä systemaattisesti avoimen skaalan astemääritteitä vähän, melko, hyvin ja erittäin sekä luvussa 2 mainittuja sulkeisen skaalan astemääritteiden alaryhmä. Jälkimmäisiin kuuluvat täyteyden astemääritteet täysin ja osittain, rajaavat aivan ja ihan, approksimatiiviset melkein ja lähes sekä tarkentavat täsmälleen ja tarkalleen. Lisäksi tarkastelen mittailmauksia, jotka kuvaavat etäisyyttä (kaksi metriä) sekä kvanttoriadverbeja (paljon).

Tarkasteltavat spatiaaliset grammit ryhmittelen niiden merkityksen perusteella. Topologisten grammien (luona, lähellä ja kaukana ${ }^{3}$ ) hakualue on kiintopisteen sisä- tai ulkopuolelle sijoittuva kolmiulotteinen ${ }^{4}$ tila. Suuntagrammien (kohti, ohi) merkityksessä keskeinen on vektori, joka esittää muuttujan liikesuuntaa tai orientaatiota suhteessa kiintopisteeseen: Liisa heitti lumipallon pääni ohi; Tienviitta osoittaa hiidenkirnua kohti (vektoripohjaisen analyysin adpositioiden semantiikasta esittävät Zwarts 1997 sekä Zwarts ja Winter 2000). Suuntagrammien merkityksessä vektorin ymmärretään osoittavan muuttujasta poispäin, ja muuttuja on tilanteessa aito tai fiktiivinen liikkuja. Tarkentavia

2 Kielitajun käytöstä kielentutkimuksessa ks. Hamunen ja Huumo (tulossa) sekä heidän mainitsemansa kirjallisuus.

3 Kaukana ei ole prototyyppinen topologinen grammi (näistä ks. Levinson ja Meira 2003), mutta luen sen kuitenkin tähän ryhmään, koska se ilmaisee muuttujan sijaintia kiintopisteen ulkopuolella spesifioimatta suuntaa. Lisäksi kaukana toimii selvemmin topologisen lähellä-grammin antonyymina, mistä syystä grammeja on luontevaa tarkastella yhdessä.

4 Esimerkiksi lähellä ja luona sallivat muuttujan sijainnin paitsi samalla horisontaalisella tasolla kiintopisteen kanssa myös tämän ylä- tai alapuolella: Helikopteri kierteli ilmassa jalkapallokentän luona; Sukellusvene kulki lähellä merenpintaa (ks. Talmy 2005, 206). Tällöin tilanteen kanonisen tarkastelutason määrää muuttujan ja kiintopisteen oma luonne. 
grammeja taas ovat keskellä ja kohdalla. Niiden hakualue täsmentyy kohdennuspisteeseen, johon muuttuja suhteutetaan. Esimerkiksi keskellä-grammin kohdennuspiste on tavallisesti kiintopisteen kattaman kaksiulotteisen alan tai kolmiulotteisen tilan ymmärretty keskipiste: Seisoin keskellä jalkapallokenttää (ala), Antti Ahven ui kalaparven keskellä (kolmiulotteinen tila). Toisinaan kohdennus ei kuitenkaan keskity pisteeseen, vaan esimerkiksi keskilinjaan ${ }^{5}$ (Auto ajoi keskellä tietä).

Tarkastelussa on tärkeää ottaa huomioon myös ne kieliopilliset konstruktiot, joissa kukin grammi voi esiintyä. Useimmat mainitsemani grammit toimivat adpositioina ja monet lisäksi adverbeina ilman täydennystä. Adverbikäytössä kiintopiste on implisiittinen ja voidaan yleensä ymmärtää puhujan tai muun näkökulmahenkilön paikaksi, esimerkiksi Traktori tuli kohti, Liisa asuu lähellä. Adpositioina grammit jakautuvat prepositioiksi, postpositioiksi ja bipositioiksi (keskellä metsää metsän keskellä). Lisäksi niiden täydennys, joka ilmaisee kiintopisteen, voi olla joko genetiivissä tai partitiivissa.

\subsection{Topologiset grammit luona, lähellä ja kaukana}

Topologiset grammit ilmaisevat muuttujan sijaintia suhteessa kiintopisteen sisä- tai ulkopuoleen täsmentämättä sijaintisuuntaa. Esimerkkeinä toimivat jo johdantoluvussa esitellyt luona ja lähellä sekä jälkimmäisen antonyymi kaukana, joka ei ole varsinainen adpositio vaan kvasiadpositio (termistä ks. Ojutkangas ja Huumo 2010), sillä se saa erosijamuotoisen kiintopisteilmauksen: Liisa asuu kaukana täältä Turusta. Zwarts (1997, 8o) mainitseekin, että 'kaukaisuutta' ilmaistaan monissa kielissä muilla kuin varsinaisilla adpositiorakenteilla.

Kaikki kolme grammia voivat esiintyä astemääritteiden kanssa, mutta lähellä ja kaukana ovat vahvasti skalaarisia, luona vain heikosti skalaarinen. Lähellä ja kaukana kelpuuttavat sekä avoimen että sulkeisen skaalan astemääritteitä, kun taas luona sallii vain muutamat sulkeisen skaalan astemääritteet. Talmyn (2017, 315-316) termein lähellä on keskihakuinen, kaukana keskipakoinen. Keskihakuisen lähellä-grammin skalaarisuus voidaan ymmärtää muuttujan sijainnin suuntaisena tarkasteluna, joka supistaa käsitteistäjän huomion kohteena olevaa aluetta vähitellen, kunnes muuttuja paikannetaan. Vastaavasti keskipakoinen kaukana laajentaa huomion alaa vähitellen loitommas kiintopisteestä niin kauan, että muuttuja paikannetaan. Kyse on siis joko kiintopistettä samanaikaisesti joka suunnasta lähestyvästä tai siitä joka suuntaan loittonevasta selauksesta ${ }^{6}$ eli aste asteelta etenevästä tarkastelusta (engl. scanning; ks. esim. Langacker 2008). Kuvio 1 havainnollistaa lähellä-grammin skalaarisuutta.

Lähellä-grammin skalaarisuus näkyy astemääritteiden laajan käyttöpotentiaalin lisäksi siinä, että grammista voidaan muodostaa komparaatiomuodot lähempänä ja lähimpänä. Komparatiivin merkityksessä on mukana kaksi kiintopistettä. Esimerkiksi Liisa asuu meitä

5 Kiitän Sananjalan nimetöntä arvioitsijaa tästä huomiosta.

6 Suomenkielisen termin selaus on esittänyt Outi Duvallon (2019). 


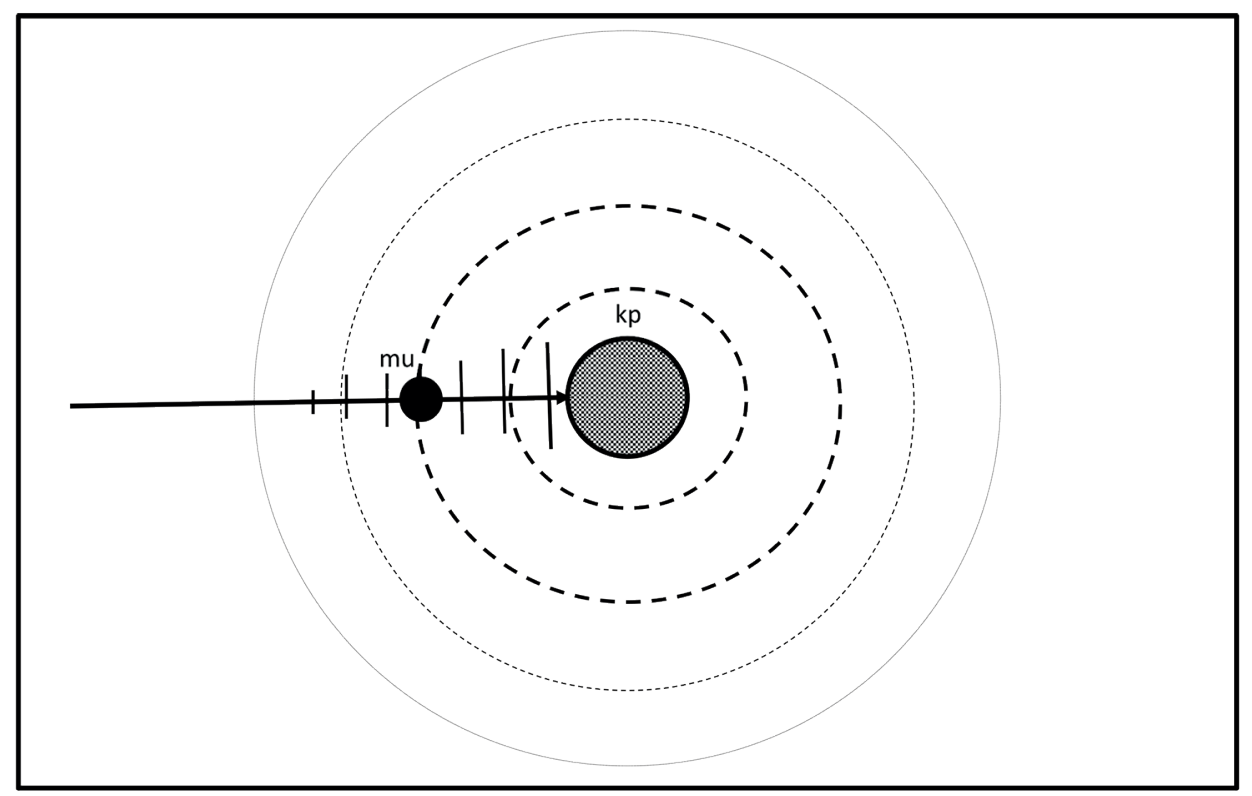

Kuvio 1. Lähellä-grammin skalaarisuus. Muuttuja $(\mathrm{mu})$ asemoidaan suhteessa kiintopisteeseen (kp). Nuolen suunta ja sen poikkiviivojen kasvava pituus kuvaavat relaation skalaarisuutta, joka kasvaa sitä mukaa, mitä lähempänä kiintopistettä muuttuja sijaitsee. Hakualueella ei ole selkeää ulkorajaa, vaan relaatio on suhteellinen. Tätä ilmentävät kiintopistettä ympäröivät renkaat, jotka ovat sitä heikompia, mitä etäämmällä kiintopisteestä ollaan.

lähempänä keskustaa asemoi muuttujan (Liisan) asuinpaikan yhtäältä (a) 'keskustaan', toisaalta (b) 'meihin'. Nimitän (a)-tyyppistä kiintopistettä peruskiintopisteeksi ja (b)tyyppistä vertailukiintopisteeksi. Vertailukiintopiste on yleensä jollain tapaa muuttujan kaltainen. Sen sijaintia suhteutetaan peruskiintopisteeseen samaan tapaan kuin muuttujan sijaintia, ja tyypillistä lienee, että vertailukiintopiste ja muuttuja ovat ontologisesti samanlaisia (esimerkiksi ihmisiä). Komparatiivirakenteessa vertailukiintopiste voidaan ilmaista partitiivimuodolla tai kuin-rakenteella, peruskiintopiste aina partitiivilla: Heikki asuu meitä lähempänä keskustaa; Kioski on lähempänä kirkkoa kuin kauppa. Superlatiivirakenteessa vertailu kohdistuu joukkoon entiteettejä, joita voidaan ajatella implisiittisiksi vertailukiintopisteiksi. Muuttujaksi valittu, lähimpänä peruskiintopistettä sijaitseva entiteetti toteuttaa sijaintisuhteen skalaarisesti korkeimmalla asteella. Vertailukiintopistettä voidaan haluttaessa ilmaista elatiivilla: Heikki seisoo (meistä) lähimpänä ovea.

Erilaisten astemääritteiden käyttömahdollisuudet lähellä-grammin märitteinä riippuvat myös siitä, millaisessa konstruktiossa grammia käytetään. Genetiivitäydennyksen kanssa postpositiona esiintyvä lähellä kelpuuttaa vain eräitä sulkeisen skaalan 
astemääritetyyppejä. Näihin lukeutuvat ensinnäkin rajaavat ihan ja aivan: Kioski on ihan aivan tuomiokirkon lähellä. Mahdollisia ovat myös approksimatiiviset melkein ja lähes, mutta ne toimivat tällöin nähdäkseni ensisijaisesti kommenttiadverbiaaleina (astemääritteen ja kommenttiadverbiaalin rajankäynnistä ks. Orpana 1988): Kioski on melkein tuomiokirkon lähellä ('melkeinpä; lähestulkoon'). ${ }^{7}$ Kommenttiadverbiaaliksi ymmärtäminen johtunee siitä, että lähellä-grammin hakualueella ei ole selvää ulkorajaa, johon approksimatiivinen astemäärite voisi suhteuttaa muuttujan sijainnin. Jos tulkinta varsinaisiksi astemääritteiksi kuitenkin tehdään, niin tällainen ulkoraja täytyy olettaa mukaan ilmauksen merkitykseen. Täyteyden ja tarkentavat astemääritteet eivät ole luontevia lähellägrammin määritteinä ilmeisesti siksi, että topologinen grammi on niille merkitykseltään liian epätäsmällinen (?täysin kirkon lähellä; ?tarkalleen kirkon lähellä).

Myös partitiivitäydennyksen yhteydessä samat rajaavat ja approksimatiiviset astemääritteet ovat mahdollisia: Kioski on ihan aivan (?)melkein 'melkeinpä lähellä tuomiokirkkoa. Partitiivitäydennys mahdollistaa kuitenkin myös avoimen skaalan astemääritteet. Näiden on sijaittava välittömästi grammin edellä: Melko hyvin erittäin lähellä kirkkoa on kukkakauppa tai Kirkkoa melko hyvin erittäin lähellä on kukkakauppa (mutta: ${ }^{*}$ melko hyvin $\sim$ erittäin kirkkoa lähellä). Kieliopillisesti tämä tarkoittaa, että astemäärite liittyy nimenomaan grammiin itseensä eikä koko adpositiolausekkeeseen: [[erittäin lähellä] kirkkoa] (ks. ISK \$ 699). Avoimen skaalan astemääritteistä omanlaisensa tulkinnan saavat kvanttoriadverbityyppiset lieventimet (englanniksi attenuating modifiers) eli matalaa astetta ilmaisevat vähän ja hiukan. Adjektiivinmääritteinä ne sopivat parhaiten yhteen merkitykseltään negatiivisten adjektiivien kanssa (vähän ruma, hiukan ikävä; ks. Paradis 1997, 76, 91; 2001, 8). Grammien astemääritteinä lieventimet implikoivat helposti sellaisen lisämerkityksen, että relaation aste ylittää jonkinlaisen normin tai optimaalisuuden rajan (adjektiivien osalta ks. mt., 76). Esimerkiksi Seisot vähän lähellä sitä kokkoa toimii varoituksena ('vaarallisen lähellä'). Vähän implikoi normin ja ilmaisee sen ylittävää astetta. Samoin käyttäytyvät eräät muut $n$-loppuiset avoimen skaalan astemääritteet (liian lähellä, turhan lähellä).

Lieventimet ovat muodoltaan kvanttoriadverbeja, mutta kaikki kvanttoriadverbit eivät toimi astemääritteinä. Esimerkiksi paljon, jonkin verran ja valtavasti eivät sovi perusmuotoisen lähellä-grammin sen paremmin kuin perusmuotoisten adjektiivienkaan astemääritteiksi ( ${ }^{\star}$ Asumme paljon lähellä tuomiokirkkoa; ${ }^{*}$ Kallu on paljon mukava). Ne kuitenkin sopivat lähempänä-komparatiivimuodon sekä adjektiivien komparatiivimuotojen määritteiksi ilmaisemaan muuttujan ja vertailukiintopisteen välimatkaa ja samalla näiden etäisyyseroja peruskiintopisteeseen: Merkurius sijaitsee Maata paljon jonkin verran valtavasti lähempänä Aurinkoa. Lisäksi komparatiivirakenteeseen sopivat etäisyyden ilmaukset, jotka samoin ilmaisevat muuttujan ja vertailukiintopisteen välimatkaa: Heikki

7 Internetistä poimittu esimerkki samasta rakenteesta: Vieras tuntuukin olevan pysyvämpää sorttia. Käyn usein melkein sen lähellä, mutta sitten juoksen pois. (Blogiteksti, jossa kirjoittajaksi ajatellaan kissa; "vieras" on taloon hiljattain saapunut vauva). 
asuu meitä pari kilometriä lähempänä keskustaa. Komparatiivimuodon yhteyteen eivät toisaalta sovi monet sellaiset astemääritteet, jotka voivat määrittää perusmuotoa lähellä ( ${ }^{\star}$ aivan $\sim{ }^{*}$ melko $\sim{ }^{*}$ erittäin lähempänä). Approksimatiivinen melkein sopii kuitenkin komparatiivimuodonkin yhteyteen (Heikki seisoo melkein lähempänä ovea kuin Liisa).

Lähellä-grammin antonyymi on keskipakoinen kaukana, joka ei ole varsinainen adpositio vaan toimii adverbina tai erosijaisen seuralaisen kanssa järjestyvänä kvasiadpositiona. Myös kaukana kelpuuttaa avoimen skaalan astemääritteet vähän, melko, hyvin ja erittäin. Lieventimien vähän ja hiukan tehtävään liittyy jälleen implikaatio normista, joka ylitetään: Asunnon sijainti on mukava, mutta ruokakauppa on vähän kaukana ('turhan kaukana'). Sulkeisen skaalan astemääritteet, kuten rajaavat aivan ja ihan, sitä vastoin vaativat erityiskontekstia ollakseen luontevia kaukana-grammin kanssa: ?Heikki asuu aivan ihan kaukana. Tämä johtuu siitä, että kaukana ei ilmaise sellaista raja-arvoa kuin lähellä, jonka raja-arvona on muuttujan ja kiintopisteen kontakti. Konteksti voi kuitenkin synnyttää raja-arvon, jona voi toimia esimerkiksi keskustelukumppanien näköpiiri: Kirkontorni näkyy tuolla, ihan kaukana 'näköpiirin äärirajoilla'. Äärirajan puuttumisen vuoksi myös approksimatiiviset melkein ja lähes toimivat kaukana-grammin yhteydessä lähinnä vain kommenttiadverbiaaleina: ?Heikki asuu melkein kaukana 'melkeinpä; lähestulkoon' Täyteyden ja tarkentavat astemääritteet eivät nekään ole aivan luontevia kaukana-grammin määritteinä (Heikki asuu ?täysin ${ }^{8}$ ? ? tarkalleen kaukana täältä).

Astemääritteiden lisäksi muuttujan ja kiintopisteen välimatkaa voidaan ilmaista pituusmittayksiköillä. Tällöin etäisyys hahmotetaan (perus)kiintopisteestä tai vertailukiintopisteestä poispäin kasvavana: Merenranta on sata kilometriä kaukana täältä; Saukkokin näyttää pyörivän alueella, oli kävellyt toista kilometriä kaukana mistään suuremmasta purosta tai lammesta (Internet); Liisa asuu meitä kaksi kilometriä kauempana keskustasta. Tällainen etäisyys on aina keskipakoista, sillä se kasvaa perus- tai vertailukiintopisteestä poispäin, ei sitä kohti. Pituusmittailmaukset ovat siksi yhteensopivia juuri kaukana-grammin kanssa, joka itsekin ilmaisee skalaarisesti kasvavaa etäisyyttä. Keskihakuinen lähellä sitä vastoin ilmaisee skalaarisesti kasvavaa läheisyyttä, joka on suunnaltaan vastakkainen mittailmausten kuvaamalle etäisyydelle. Siksi sen tapaiset ilmaukset kuin ?kaksi metriä lähellä ovat yleensä outoja, vaikka sellaisiakin joskus esiintyy. ${ }^{9}$

Grammi luona on Talmyn (2017) esittämässä jaottelussa ei-skalaarinen tai korkeintaan heikosti skalaarinen ${ }^{10}$. Se ei komparoidu eikä sovi yhteen avoimen skaalan astemääritteiden kanssa ( ${ }^{\star}$ melko kirkon luona, ${ }^{*}$ erittäin kirkon luona). Semanttisten seikkojen lisäksi syynä on se, että luona on yksinomaan genetiivimääritteen kanssa järjestyvä postpositio, jollaiset eivät yleensäkään kelpuuta avoimen skaalan astemääritteitä. Luona

8 Ilmaus täysin kaukana ei silti ole epäkieliopillinen: joitakin esiintymiä löytyy internetistä, kuten asunnon sijaintia kuvaileva Lähellä moottoritietä, mutta täysin kaukana melusta.

9 Yksi esimerkki on matkailusivustolta löytämäni kuvaus loma-asunnosta, jonka mainitaan sijaitsevan 50 metriä lähellä merta.

10 Talmy tarkastelee vain avoimen skaalan astemääritteitä (very), joten hänen luokittelussaan sulkeisen skaalan astemääritteitä määritteikseen hyväksyvät prepositiot lukeutuvat ei-skalaarisiksi. 


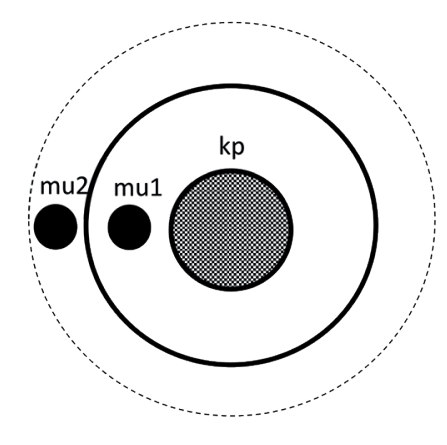

Kuvio 2. Luona-grammin heikosti skalaarinen merkitys. Hakualue on selvärajainen (kiintopistettä ympäröivä yhtenäinen viiva), ja sen sisäpuolella oleva muuttuja (mul) on kiintopisteen (kp) luona. Hakualuetta ympäröi approksimatiivinen vyöhyke (katkoviiva), jolla sijaitseva toinen muuttuja (mu2) on melkein kiintopisteen luona (esimerkiksi Raitiovaunu on nyt melkein kirkon luona).

sopiikin hyvin yhteen kognitiivisen kieliopin perinteisten adpositiokuvausten kanssa, joissa adposition tehtäväksi esitetään muuttujan asemointi selvästi rajautuvalle hakualueelle (search domain; Langacker 1999, luku 3). Toisin kuin lähellä-kaukana-antonyymiparilla, luona-grammilla ei ole selkeää antonyymia (erilaisia antonymiasuhteita käsittelee perusteellisesti Hakanen 1973, 35-44). Luona-grammin skalaarisuutta esittää kuvio 2.

Heikosti skalaarisesta luonteestaan huolimatta luona voi esiintyä eräiden sulkeista skalaarisuutta ilmaisevien astemääritteiden kanssa. Luontevimpia ovat rajaavat ihan ja aivan: Kioski sijaitsee aivan kirkon luona; Liisa seisoi ihan oven luona. Nämä tarkoittavat, että muuttujan sijainti asettuu selvästi ja kiistatta hakualueelle ja sen sisällä erityisen lähelle kiintopistettä. Myös approksimatiiviset melkein ja lähes ovat mahdollisia: Liisa seisoo melkein oven luona; Raitiovaunu on nyt melkein kirkon luona. Jälkimmäinen esimerkki implikoi liikkeen, jossa muuttuja (raitiovaunu) on saapumassa hakualueelle. Melkein saa samalla myös temporaalisen tehtävän: se kertoo, että kuvattavalla hetkellä 
grammin ilmaisema sijaintisuhde on lähellä toteutumistaan. ${ }^{11}$ Myös staattista sijaintia kuvaavissa luona-grammin käytöissä melkein on mahdollinen, jos tilanteeseen liittyy vaiheittain etenevä selaus. Esimerkiksi Kukkakauppa on melkein kirkon luona on luonteva tilanteessa, jossa arvioidaan matkaa (puhepaikasta) kukkakaupalle. Tällaisissa konteksteissa luona saa tarkentavan grammin tapaisen tehtävän, jossa se muistuttaa erityisesti kohdalla-grammia (tästä lisää luvussa 3·3).

Lieventimet vähän ja hiukan ovat muiden avoimen skaalan astemääritteiden tapaan epäluontevia luona-grammin astemääritteinä: ??Kukkakauppa sijaitsee vähän kirkon luona. Myös sulkeisen skaalan määritteisiin kuuluvat täyteyden astemääritteet ovat vastahankaisia: ??Kukkakauppa sijaitsee täysin kirkon luona. Etäisyyden ilmaukset eivät sovi ollenkaan luona-grammin yhteyteen, vaan johtavat epäkieliopillisuuteen: ${ }^{\star} k a k s i$ metriä kirkon luona. Sitä vastoin tarkentava täsmälleen on mahdollinen etenkin silloin, kun kuvataan liiketilannetta: Raitiovaunu on nyt täsmälleen kirkon luona.

\subsection{Suuntagrammit kohti ja ohi}

Suuntaa ilmaisevien grammien astemäärite liittyy muuttujan liikesuunnan tai orientaation määritykseen. Orientaatiolla tarkoitan suuntautumista, johon ei liity varsinaista liikettä, esimerkiksi Katsokaa minuun päin! tai Tienviitta osoitti museota kohti. Tarkoitetilanteessa toteutuvaa muuttujan liike- tai orientaatiosuuntaa esittävää vektoria nimitän toteutumavektoriksi. Suuntagrammien merkityksen kuvaamiseksi tarpeellisia käsitteitä ovat myös ideaalivektori, joka tarkoittaa muuttujasta suoraan kiintopisteen keskikohtaan (tai muuhun kiintopisteen alalla olevaan kohdennuspisteeseen, esimerkiksi ihmiskiintopisteen kasvoihin) osoittavaa vektoria, sekä kontaktisektori, joka kattaa ne muuttujasta alkunsa saavat toteutumavektorit, joita noudattava liike johtaisi muuttujan ja kiintopisteen kontaktiin (ks. kuviota 3 alempana). Suuntagrammit ovat läheistä sukua väylägrammeille, joita ovat esimerkiksi pitkin, läpi ja yli (näistä ks. Huumo 2010; Lehismets 2013; Hamunen tulossa). Esimerkiksi tässä alaluvussa tarkasteltava grammi ohi voi ilmaista sekä suuntaa (Tähtäsin tahallani maalitaulun ohi) että väylää (Bussi 7 kulkee sairaalan ohi). Suunnan ja väylän keskeinen ero on se, että suunta on suora vektori, jolla on määräsuunta ja tietty alkupiste (tavallisesti muuttujan asema tai näkökulmapaikka), väylä taas voi olla myös

11 Adverbilla melkein esiintyy muutenkin monitulkintaisuutta, joka näyttäisi puuttuvan muilta astemääritteiltä. Esimerkiksi Astiat ovat melkein puhtaita voi 'puhtauden' approksimatiivisen asteen ('lähespuhtaita') ilmaisemisen lisäksi aikaansaada ajallisen implikaation siitä, että astiat ovat puhdistettavina ja hetken kuluttua täysin puhtaita. Tällöin ominaisuus voi liittyä joko kokonaisvaltaisesti kaikkiin tarkoitettuihin astioihin (joita pestään samanaikaisesti, esimerkiksi koneella, ja pesuohjelma on lähestymässä loppuaan) tai vaiheittain vain osaan astioista (joita ollaan pesemässä yksi kerrallaan). Jälkimmäisessä tulkinnassa jo pestyt astiat saattavat olla täysin puhtaita, pesemättömät vielä täysin likaisia. Tällöin approksimatiivisuus liittyy pikemminkin tarkoitteen kvantiteettiin kuin ominaisuuden asteeseen. Vastaavia tulkintoja ei synny esimerkiksi avoimen skaalan astemääritteelle melko lauseessa Astiat ovat melko puhtaita, joka ilmaisee puhtauden asteen holistisesti (kaikkia tarkoitettuja astioita koskevaksi) ja vailla muutoksen implikaatiota. 
epäsuora (ks. Sivonen 2005), eikä sillä ole luontaista määräsuuntaa. Esimerkiksi kirkkoa kohti (suunta) liikutaan määräsuuntaan, puiston läpi (väylä) taas voi kulkea käytännössä mihin suuntaan tahansa, kunhan kulkija on matkan jossain vaiheessa puiston alalla.

Käsittelen tässä luvussa yksityiskohtaisimmin suuntagrammia kohti, jota voinee pitää ryhmän prototyyppisenä jäsenenä, ja lisäksi grammia ohi, joka voi ilmaista suuntaa (Tähtäsin tahallani maalitaulun ohi) mutta myös kiintopisteen sivuuttavaa väylää (Juna kolisteli pysähtymättä aseman ohi). Toisinaan molemmat merkitykset ovat mukana (Liisa heitti lumipallon Heikin pään ohi). Muita suuntaa ilmaisevia grammeja ovat esimerkiksi päin ja poispäin, joita en käsittele.

Grammi kohti ilmaisee muuttujan liikkeen tai orientaation suuntaa. Esimerkiksi lauseessa Juoksin kirkkoa kohti ilmaistaan liikkeen suunta, lauseessa Tienviitta osoitti kirkkoa kohti orientaation suunta. Talmy (2000, 106-111) pitää jälkimmäisen kaltaisia ilmauksia fiktiivisen liikkeen alatyyppinä: osoittaminen, suuntautuminen tai esimerkiksi katseen kohdistaminen perustuvat hänen mukaansa käsitteistykseen fiktiivisestä signaalista, joka liikkuu tilanteessa läsnä olevien, paikallaan pysyvien tarkoitteiden välillä (suomen aistihavaintoverbien kannalta ks. Huumo 2005). Adpositiokäytössään kohti on partitiivitäydennyksen kera esiintyvä bipositio (kirkkoa kohti kohti kirkkoa). Adverbina kohti ilmaisee suuntaa, joka kohdistuu implisiittiseen näkökulmapaikkaan, esimerkiksi Ihmettelimme, miksi traktori tuli kohti; Kyllähän siinä pelästyy, kun ryöstäjä osoittaa aseella kohti.

Liikkeen ilmauksissa kohti jättää avoimeksi, saavuttaako liikkuva muuttuja lopulta kiintopisteen vai ei. Näin se tekee liiketilanteesta aspektiltaan rajaamattoman (ks. Zwarts 2005) ja mahdollistaa määritteet, jotka ilmaisevat kuljettua matkaa tai liikkeeseen kuluvaa aikaa: Juoksin vähän matkaa sata metriä parikymmentä askelta kaksi minuuttia kirkkoa kohti. Pelkkää orientaatiota ilmaistaessa tällaiset ilmaukset eivät ole luontevia, sillä ei ole selvää, mitä ne mittaisivat: Tienviitta osoittaa ?vähän matkaa ?sata metriä ${ }^{\star} k a k s i$ minuuttia ${ }^{12}$ kirkkoa kohti.

Merkitysalassaan kohti kattaa kaikki kontaktisektoriin sisältyvät toteutumavektorit. Kontaktisektoria voikin kognitiivisen kieliopin termein pitää kohti-grammin hakualueena. Kaikki kontaktisektorille sisältyvät toteutumavektorit eivät silti ole samanarvoisia grammin merkityksen toteutumia, sillä kohti on lisäksi skalaarinen. Sen skalaarisuudessa, joka on sulkeista tyyppiä, korkeinta astetta edustaa toteutumavektori, joka osuu yhteen ideaalivektorin kanssa. Toteutumavektori, joka poikkeaa ideaalivektorista, edustaa matalampaa skalaarisuuden astetta. Hakualueen ulkopuolelle jäävät ne toteutumavektorit, jotka eivät sijoitu kontaktisektorille. Niinpä kohti kelpuuttaa luontevimmin sulkeisen skaalan astemääritteitä: rajaavat ihan ja aivan, approksimatiiviset melkein ja lähes ja tarkentavat täsmälleen ja tarkalleen sopivat kaikki sen määritteiksi, esimerkiksi Juoksimme ihan lähes täsmälleen kirkontornia kohti (liikesuunta); Käänsin tienviitan osoittamaan

12 Ilmauksen kielenvastaisuus liittyy tulkintaan, jossa kaksi minuuttia kuvaa väylällä tapahtuvan fiktiivisen liikkeen kestoa. Jos se kuvaa kokonaistilanteen kestoa, se on hyväksyttävä: 'Kahden minuutin ajan tienviitta osoittaa kirkkoa kohti' (sitten joku kääntää sen osoittamaan muualle). 


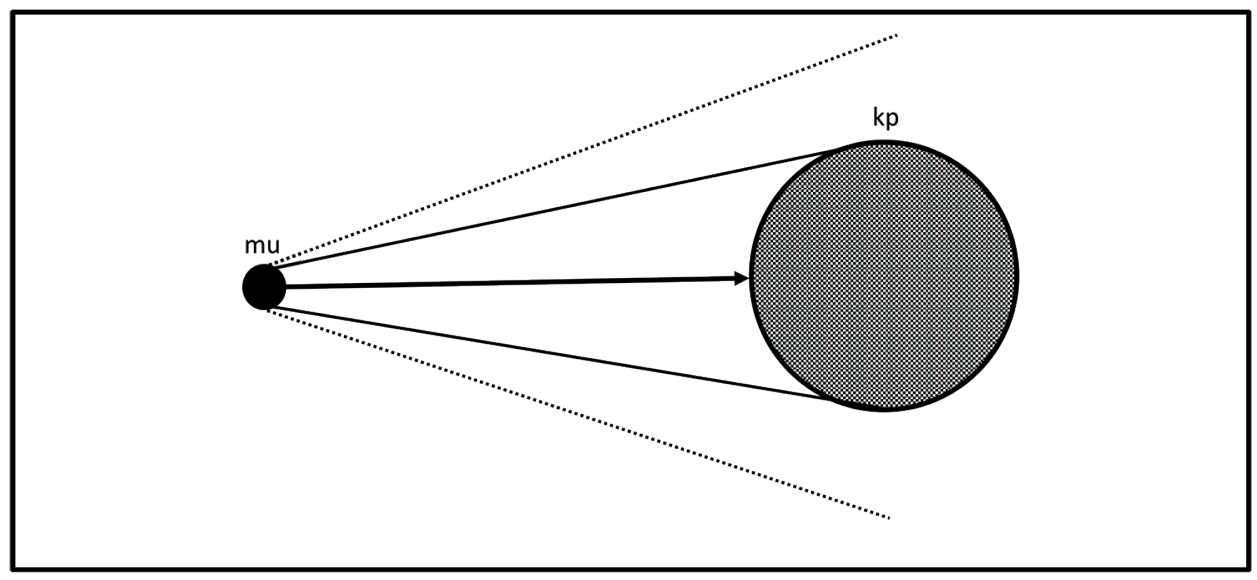

Kuvio 3. Kohti-grammin skalaarisuus: nuoli kuvaa ideaalivektoria ja samalla relaation maksimaalista astetta (ihan täsmälleen kohti). Yhtenäiset, muuttujasta (mu) kiintopisteen (kp) reunoihin kulkevat viivat kuvaavat hakualueena toimivaa kontaktisektoria (kohti). Katkoviivat kuvaavat approksimatiivista sektoria (melkein kohti).

aivan $\sim$ melkein $\sim$ tarkalleen hiidenkirnua kohti (orientaatio). Näistä rajaavat ihan ja aivan sekä tarkentavat täsmälleen ja tarkalleen kuvaavat toteutumavektoria, joka lankeaa yhteen ideaalivektorin kanssa. Approksimatiiviset melkein ja lähes puolestaan kuvaavat toteutumavektoria, joka jää niukasti kontaktisektorin ulkopuolelle (kuvio 3 ).

Lieventiminä yleensä toimivat vähän ja hiukan ovat nekin mahdollisia kohti-grammin määritteinä, mutta niiden ensisijainen tehtävä ei liity toteutumavektorin suunnan määritykseen, vaan ne ilmaisevat toteutumavektorin suunnassa kuljettua matkaa: Kävelin vähän hiukan kirkkoa kohti. ${ }^{13}$ Siksi ne (samoin kuin edellä mainitsemani etäisyyden ilmaukset) eivät ole aivan luontevia tilanteissa, joissa grammi ilmaisee pelkkää orientaatiota: ?Opasnuoli osoitti vähän hiukan hiidenkirnua kohti.

Avoimen skaalan astemääritteet eivät sovi kohti-grammia määrittämään, vaikka kieliopilliselta kannalta tämä olisi periaatteessa mahdollista grammin täydennyksen partitiivisijan perusteella: ${ }^{\star} J$ uoksimme erittäin kohti kirkkoa; ${ }^{\star}$ Nuoli osoitti melko kohti museota. Adverbikäytössä avoimen skaalan astemääritteet ovat kuitenkin vain vastahankaisia, eivät epäkieliopillisia: ?Traktori tuli melko kohti. ${ }^{14}$

Kohti-grammin semanttisena vastaparina toimii ohi, jonka ilmaisema toteutumavektori jää kontaktisektorin ulkopuolelle: Heitin viimeisen tikan taulun ohi; Tienviitta

13 Suuntamerkityskin on joskus mahdollinen; sitä ilmaisee esimerkiksi kiteytynyt ilmaus vähän 'suunnilleen' sinnepäin.

14 Internetistä poimittu esimerkki: Hotelli sijaitsee melko kohti sataman sisäänkäyntiä, ja ravintolassa on tyypillinen italialainen valikoima elintarvikkeita. 
oli väännetty osoittamaan hiidenkirnun ohi umpimetsään. Kohti-grammin tapaan ohi on bipositio, mutta siitä poiketen ohi järjestyy aina genetiivin kanssa (kylän ohi ohi kylän). Myös ohi voi esiintyä adverbina (Vaikka yritin keskittyä, viimeinen tikka meni ohi).

Suuntaa ilmaisevan ohi-grammin hakualueena ovat periaatteessa kaikki sektorit, joille sijoittuvaa toteutumavektoria noudattava liike ei johtaisi muuttujan kontaktiin kiintopisteen kanssa. Esimerkiksi tikkataulun ohi menevän tikan reitti voi sivuuttaa taulun miltä puolelta hyvänsä. Ohi-grammin käytön lisäehtona kuitenkin on, että toteutumavektori ei poikkea liikaa kontaktisektorilta. Poikkeaman on oltava kohtuullinen, sillä grammin suuntamerkitys kontrastoituu siihen vaihtoehtoon, että toteutumavektori jäisikin kontaktisektorille. Ohi-grammin luontevuus heikkenee toteutumavektorin poiketessa yhä enemmän kontaktisektorilta samalla, kun itse skalaarisuuden aste kasvaa. Jos esimerkiksi heitän lumipallon kokonaan poispäin Heikistä tai suuntaan, joka on kohtisuorassa minusta Heikkiin osoittavan ideaalivektorin kanssa, ei ole luontevaa sanoa lumipallon menneen Heikin ohi.

Skalaarisuudeltaan ohi perustuu kohti-grammin tavoin toteutumavektorin suunnan arviointiin mutta on tälle vastakkainen sikäli, että skalaarisuus kasvaa sitä suuremmaksi, mitä enemmän toteumavektori poikkeaa kontaktisektorilta. Kohti-grammin tapaan ohi esittää skalaarisuuden sulkeisena ja kelpuuttaa luontevimmin sulkeisen skaalan astemääritteitä kuten melkein, aivan ja ihan. Approksimatiivinen melkein ohi ilmaisee, että toteutumavektori jää täpärästi kontaktisektorin sisäpuolelle: Heitin viimeisen tikan melkein taulun ohi. Rajaavat aivan ja ihan taas merkitsevät, että toteutumavektori jää kontaktisektorin ulkopuolelle selvällä marginaalilla: Heitin viimeisen tikan aivan ohi; Alokas tähtäsi aseellaan ihan maalitaulun ohi. Lieventimet vähän ja hiukan sekä täyteyden astemäärite täysin toimivat samaan tapaan kuin mitan ilmaukset, jotka (suuntaa merkitsevän) ohigrammin yhteydessä ilmaisevat toteutumavektorin poikkeamaa kontaktisektorilta: Heitin viimeisen tikan vähän $~ 20$ senttiä täysin [taulun] ohi. Tarkentavat astemääritteet taas vaativat erityistä kontekstia ollakseen luontevia ohi-grammin kanssa. Esimerkiksi ?Heitin tikan täsmälleen taulun ohi on outo, mutta Veitsenheittäjä tähtäsi täsmälleen avustajan korvan ohi on mahdollinen.

Avoimen skaalan astemääritteet eivät luontevasti sovi ohi-grammin määritteiksi. Adpositiorakenteissa ne ovat epäkieliopillisia jo siksi, että ohi järjestyy genetiivin kanssa ( ${ }^{*}$ erittäin melko taulun ohi), mutta myös adverbikäytöt ovat vastahankaisia (?Viimeinen tikka meni melko erittäin ohi $\left.{ }^{15}\right)$.

Suuntamerkityksensä lisäksi ohi voi ilmaista liikeväylää, jolla etenevä muuttuja sivuuttaa kiintopisteen päätymättä tämän kanssa kontaktiin. Tällaisessa merkityksessä kontaktisektori ei ole relevantti: liikkeen suuntaa ei esitetä poikkeamana kontaktisektorilta vaan etenemisenä väylällä, joka sivuuttaa kiintopisteen ilman, että muuttujan ja kiintopisteen kontakti ymmärrettäisiin vaihtoehdoksi. Esimerkkejä ovat Bussi numero 7 menee

15 Lähinnä kuvakielisistä ilmauksista tämäntyyppisiä käyttöjä voi silti löytää internetistä (esimerkiksi Tämä kappale menee melko ohi; Joulu on jo erittäin ohi). 
keskussairaalan ohi ja fiktiivisen liikkeen ilmaus Liisankatu menee kirkon ohi. Tällaisten lauseiden muuttuja ei pyrikään kontaktiin kiintopisteen kanssa vaan etenee (aidosti tai fiktiivisesti) pitkin ennalta määrättyä väylää, joka sivuuttaa kiintopisteen. Väylä kuitenkin suhteutetaan aina kiintopisteeseen, ja sen on kuljettava suhteellisen läheltä kiintopistettä, jotta ohi-grammin käyttö olisi luontevaa.

Astemääritteet saattavat ohi-grammin yhteydessä liittyä jompaankumpaan näistä merkitystehtävistä tai olla yhteensopivia kummankin kanssa ja siten kaksitulkintaisia. Kun ohi ilmaisee väylää (eikä siis suuntaa), approksimatiivinen melkein liittyy siihen, miten väylällä kuljettu matka suhteutuu kiintopisteeseen: Jäisellä tiellä bussi liukui melkein pysäkin ohi ennen kuin pysähtyi. Vastaavasti rajaava Bussi liukui ihan pysäkin ohi tarkoittaa, että kiintopisteen sivuuttaminen toteutui täydellisesti esimerkiksi niin, että koko bussin runko sivuutti pysäkin ennen pysähtymistä. Myös lieventimet vähän ja hiukan sekä matkan ilmaukset kuten kymmenen metriä voidaan tulkita näin (Bussi liukui vähän kymmenen metriä pysäkin ohi). Toisaalta tällaiset ilmaukset voivat liittyä myös grammin suuntamerkitykseen, jolloin ne ilmaisevat toteutumavektorin poikkeamaa kontaktisektorilta. Esimerkiksi Heittämäni pallo meni kaksi metriä maalitaulun ohi voi näin ollen tarkoittaa joko 'kahden metrin etäisyydeltä' (vektoritulkinta) tai 'kahden metrin matkan' (väylätulkinta).

\subsection{Tarkentavat grammit keskellä ja kohdalla}

Tässä alaluvussa käsittelen grammeja, joita kutsun tarkentaviksi. Niiden merkitystä voi luonnehtia tähtäimen kaltaiseksi: muuttujan asemointi keskittyy kohdennuspisteen ympärille. Mitä lähempänä muuttuja on kohdennuspistettä, sitä korkeampaa skalaarisuuden astetta sijaintisuhde edustaa. Esimerkiksi keskellä suhteuttaa tällöin muuttujan kiintopisteen sisäpuolen tai alan keskipisteeseen, joka toimii kohdennuspisteenä (kalaparven keskellä, niityn keskellä). Myös kohdalla on tarkentava grammi, joka liittyy muuttujan sijainnin asemointiin liike- tai tarkasteluväylällä. Kohdennuspiste sijaitsee nyt väylän siinä kohdassa, joka on lähimpänä kiintopistettä, esimerkiksi Raitiovaunu on nyt kirkon kohdalla 'reittinsä siinä pisteessä, joka on lähimpänä kirkkoa'. Teknisemmin asian voi ilmaista niin, että kohdennuspisteenä on muuttujan liikeväylän sekä kiintopisteestä alkavan, muuttujan liikeväylään nähden kohtisuorassa olevan projektiosuoran leikkauspiste (ks. Talmyn 2005, 233-234 kuvausta englannin past-prepositiosta). Myös sellaista väylää, jolla ei varsinaisesti liikuta, voidaan tarkastella selaamalla muuttujan paikantamiseksi, esimerkiksi Kioski on Liisankadulla kirkon kohdalla 'Liisankadun siinä pisteessä, joka on lähimpänä kirkkoa'.

Grammi keskellä ilmaisee skalaarisessa merkityksessään muuttujan sijainnin suhteessa hakualueen keskipisteeseen. Grammilla on lisäksi myös topologistyyppinen merkitys 'kiintopisteen ympäröimänä. Jälkimmäinen korostuu Haukiojan (1998, 222-224) mukaan etenkin silloin, kun kiintopiste on tulkittavissa alaltaan rajaamattomaksi, mitä usein ilmaisee sen partitiivimuoto. Esimerkiksi Mökki on keskellä maaseutua tarkoittaa tällöin 'joka puolelta maaseudun ympäröimä' eikä 'maaseudun keskipisteessä. Keskityn 
seuraavassa kuitenkin keskellä-grammin skalaariseen merkitykseen, jossa muuttujan sijaintia suhteutetaan kiintopisteen ymmärrettyyn keskipisteeseen. Hakualueena voi tällöin olla kolmiulotteinen tila (Antti Ahven ui kalaparven keskellä) tai kaksiulotteinen pinta (Seisoin pelikentän keskellä), ja sen rajat asettaa kiintopiste itse (kalaparvi, kenttä). Hakualueeksi voidaan ymmärtää myös useista yksilöistä koostuvan kiintopisteen kollektiivisesti täyttämä ala (kalojen keskellä puiden keskellä). Sijaintirelaatio on skalaarinen, sillä se pätee sitä vahvempana, mitä lähempänä kohdennuspistettä muuttuja sijaitsee. Korkeinta astetta edustaa tilanne, jossa muuttuja sijaitsee kohdennuspisteessä.

Kieliopillisesti keskellä on bipositio, jonka täydennys vaihtelee genetiivin ja partitiivin välillä. Genetiivi esiintyy yleensä postpositiokäytössä, partitiivi prepositiokäytössä: metsän keskellä keskellä metsää (vaihtelusta ks. Haukioja 1998; Lestrade 2010). Lisäksi keskellä toimii adverbina, jonka kiintopiste on implisiittinen (Heikki seisoo keskellä). Grammin kiintopiste voidaan ilmaista myös erillisellä, esimerkiksi paikallissijaisella, adverbiaalilla (Heikki seisoo väkijoukossa keskellä). Koska keskellä-grammin ilmaisemalla relaatiolla on ääriarvona muuttujan sijainti täsmälleen kohdennuspisteessä, grammi edustaa sulkeista skalaarisuutta. Se sopiikin yhteen sulkeisen skaalan astemääritteiden, esimerkiksi approksimatiivisten ja rajaavien, kanssa: Mökki sijaitsee melkein ihan aivan metsän keskellä;

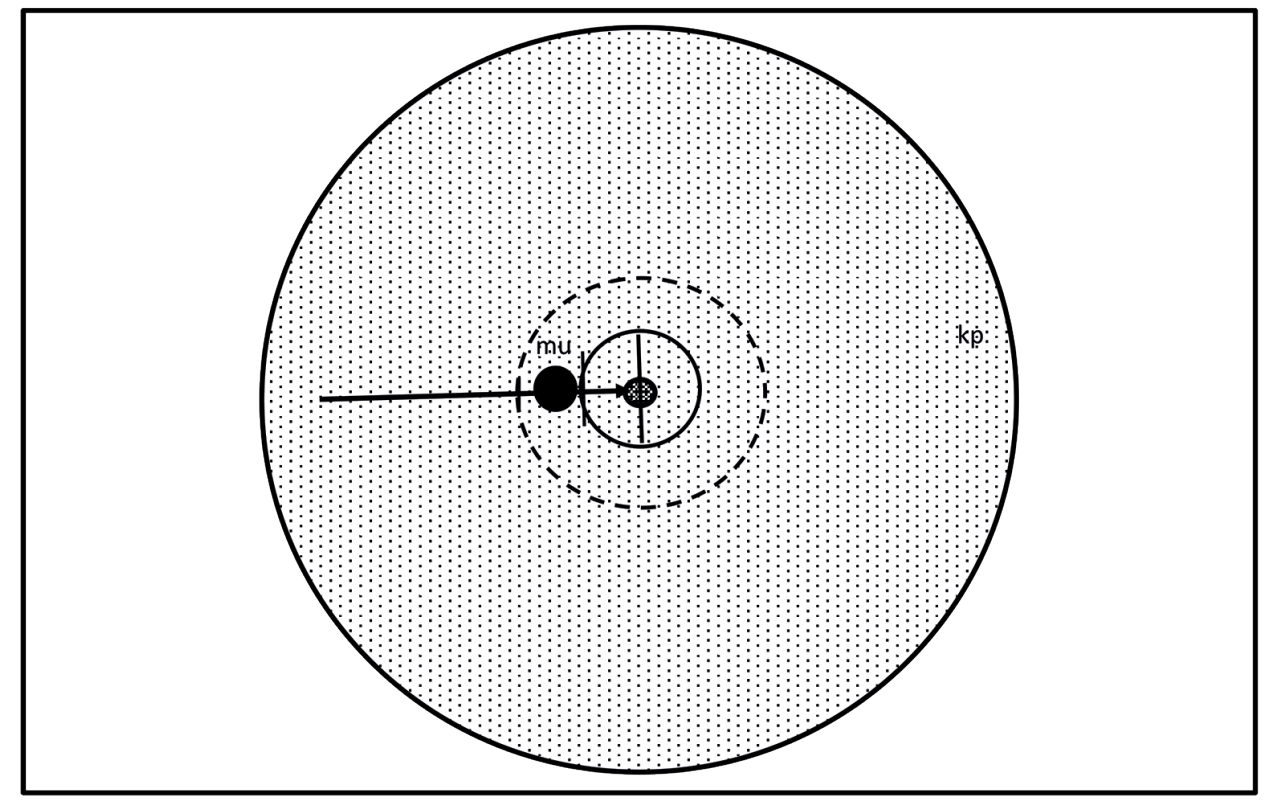

Kuvio 4. Melkein keskellä. Muuttuja (mu) on kiintopisteen (kp) kattamalla alalla. Pieni tummanharmaa pallo kiintopisteen keskellä on kohdennuspiste. Sisempi, yhtenäisellä viivalla merkitty ympyräalue on keskellä-grammin varsinainen hakualue, ja ulompi, katkoviivalla rajattu alue on approksimatiivinen alue (johon sopii kuvaus melkein keskellä). Nuoli esittää grammin keskihakuista skalaarisuutta, ja skalaarisuusasteet on merkitty nuoleen pystyviivoin. 
Heikki seisoo melkein ihan aivan keskellä peltoa. Lisäksi keskellä kelpuuttaa tarkentavat astemääritteet täsmälleen ja tarkalleen sekä täyteyden astemääritteen täysin: Mökki sijaitsee tarkalleen täysin keskellä metsää. Laita pelimerkki täsmälleen keskelle pelilautaa (kuvio 4).

Avoimen skaalan astemääritteet kuten melko ja erittäin ovat vastahankaisia keskellägrammin astemääritteinä (?Mökki sijaitsee erittäin keskellä metsää̈${ }^{16}$ ), vaikka jonkin verran tällaista käyttöä esimerkiksi internetissä esiintyykin. Tällaisessa käytössä grammin täydennyksen on joka tapauksessa oltava partitiivissa, sillä genetiivirakenne * erittäin metsän keskellä on kiistatta epäkieliopillinen.

Myös kohdalla-grammin hakualue on skalaarinen ja keskittyy kohdennuspisteeseen. Kiintopisteen oma orientaatio ei ole ratkaiseva: kohdennuspiste voi olla kiintopisteen millä puolella tahansa. Toisaalta muuttujan asemointi keskittyy nyt vain sen liikeväylän tarkasteluun eikä tarkenna kohti kohdennuspistettä kaikilta suunnilta niin kuin keskellä-grammin merkityksessä. Kohdalla-grammin kohdennuspiste on kiintopistettä lähin sijaintipaikka muuttujan liikeväylällä (Raitiovaunu on nyt kirkon kohdalla) tai muulla suuntaisesti tarkastellulla väylällä (Kukkakauppa on Liisankadulla kirkon kohdalla). Jälkimmäinen esimerkki tarkoittaa, että Liisankatua seuraileva käsitteistäjän huomion fokus saavuttaa kukkakaupan ollessaan samalla lähimpänä kirkkoa. Esimerkissä yksi tilanteen kiintopisteistä on pitkänomainen entiteetti katu ${ }^{17}$, jollaisen suuntainen tarkastelu on tyypillistä.

Keskellä-grammin tapaan kohdalla kelpuuttaa rajattuun skalaarisuuteen liittyvät astemääritteet melkein, aivan ja ihan sekä tarkentaville grammeille tyypilliset tarkalleen ja täsmälleen: Raitiovaunu on melkein $\sim$ ihan aivan $\sim$ täsmälleen kirkon kohdalla; Liisankadulla on kukkakauppa melkein $\sim$ aivan $\sim$ ihan $\sim$ täsmälleen kirkon kohdalla. Avoimen skaalan astemääritteet vähän, melko ja erittäin eivät kohdalla-grammin määritteiksi sovi, mikä kieliopillisesti seuraa jo siitä, että kohdalla on genetiivin kanssa järjestyvä postpositio. Myöskään adverbina käytetty kohdalla ei kelpuuta avoimen skaalan astemääritteitä: Heikki päätti heittää raitiovaunua lumipallolla vasta kun vaunu olisi ihan täsmälleen *erittäin kohdalla.

\section{Kokoavaa tarkastelua}

Esitän tutkimuksen keskeiset tulokset vielä kootusti taulukon muodossa. Taulukkoon 1 on merkitty erilaisten astemääritteiden ja mitan ilmausten yhteensopivuus kutakin tarkasteltua grammiryhmää edustavien esimerkkigrammien kanssa.

Taulukosta 1 käy ilmi, että astemääritteiden ja mitan ilmausten käyttöpotentiaali ja tehtävät eroavat tarkasteltujen grammiryhmien ja grammien kesken. Tarkastelen seuraavassa kokoavasti taulukosta ilmeneviä säännönmukaisuuksia astemääriteryhmä

16 Internetistä poimittu esimerkki: Joten kun olimme erittäin keskellä kaupunkia, olimme hieman jumissa. 17 Liisankatu on esimerkissä kiintopiste adessiivisijan (ei kohdalla-grammin) ilmaisemassa relaatiossa. Grammin ilmaiseman relaation kiintopisteenä on kirkko. 
Taulukko 1. Artikkelissa tarkastellut astemääritteiden ja mittailmausten ryhmät (vaakatasossa) sekä eräät keskeiset grammit (pystysuorassa). Symboli + tarkoittaa ilmausten yhteensopivuutta, symboli - yhteensopimattomuutta. Hakasulut tarkoittavat, että astemäärite on luonteva vain kommenttiadverbiaalina. Kaarisulut tarkoittavat ehdollista tai marginaalista hyväksyttävyyttä.

\begin{tabular}{|c|c|c|c|c|c|c|}
\hline & \multirow{2}{*}{$\begin{array}{l}\text { Avoimen } \\
\text { skaalan } \\
\text { astemääritteet } \\
\text { Avoin } \\
\text { (erittäin) }\end{array}$} & \multicolumn{3}{|c|}{ Sulkeisen skaalan astemääritteet } & \multicolumn{2}{|c|}{ Muut } \\
\hline & & $\begin{array}{l}\text { Rajaava } \\
\text { (ihan) }\end{array}$ & $\begin{array}{l}\text { Approksim. } \\
\text { (melkein) }\end{array}$ & $\begin{array}{l}\text { Tarkentava } \\
\text { (täsmälleen) }\end{array}$ & $\begin{array}{l}\text { Etäisyys } \\
\text { (X metriä) }\end{array}$ & $\begin{array}{l}\text { Kvanttori } \\
\text { (reilusti) }\end{array}$ \\
\hline \multicolumn{7}{|l|}{$\begin{array}{l}\text { Topologiset } \\
\text { grammit }\end{array}$} \\
\hline lähellä & + & + & {$[+]$} & - & - & - \\
\hline lähempänä & - & {$[+]$} & {$[+]$} & - & + & + \\
\hline kaukana & + & $(+)$ & {$[+]$} & - & + & - \\
\hline luona & - & + & + & - & - & - \\
\hline \multicolumn{7}{|l|}{$\begin{array}{l}\text { Suunta- } \\
\text { grammit }\end{array}$} \\
\hline kohti & - & + & + & + & + & - \\
\hline ohi & - & + & + & - & + & + \\
\hline \multicolumn{7}{|l|}{$\begin{array}{l}\text { Tarkentavat } \\
\text { grammit }\end{array}$} \\
\hline keskellä & $(+)$ & + & + & + & - & - \\
\hline kohdalla & - & + & + & + & - & - \\
\hline
\end{tabular}

kerrallaan. Koska luvun 3 käsittely eteni grammiryhmittäin, on nähdäkseni tarpeellista koota lopuksi yhteen erityyppisten astemääriteryhmien käyttäytymistä.

Sulkeisen skaalan astemääritteistä approksimatiiviset melkein ja lähes sekä rajaavat ihan ja aivan ovat erittäin laajakäyttöisiä: ne sopivat kaikissa tarkastelemissani grammiryhmissä ainakin jonkin grammin astemääritteiksi. Jos kommenttiadverbiaalikäytöt ja marginaalisesti mahdolliset käytöt otetaan huomioon, mikään tarkastelluista grammeista ei suoranaisesti torju approksimatiivisia ja rajaavia astemääritteitä (niiden yhdistelmä ei johda epäkieliopillisuuteen). Sen sijaan täyteyden astemääritteet täysin ja täydellisen sopivat yhteen vain harvojen tarkastelemieni grammien kanssa.

Approksimatiivisten ja rajaavien astemääritteiden yhteensopivuus monien grammien kanssa heijastaa sitä, että grammien ilmaisemalla relaatiolla ymmärretään olevan yhtäältä alku- tai minimiraja ja toisaalta maksimiarvo, jonka saavuttaa ilmaistun relaation täydellisesti toteuttava muuttuja. Maksimiarvon luonne vaihtelee grammeittain. Keskihakuisesti tulkittujen grammien maksimiarvo perustuu muuttujan sijaintiin mahdollisimman 
lähellä kiintopistettä. Tällaista skalaarisesti kasvavaa läheisyyttä voidaan ilmaista ainakin topologisten grammien yhteydessä (ihan kirkon lähellä). Keskihakuisuuden lisäksi rajaavat ja approksimatiiviset astemääritteet voivat täsmentää suhdetta ideaalivektoriin (Heitin tikan ihan melkein kohti napakymppiä) tai kohdennuspisteeseen (Mustikkapaikka on ihan melkein metsän keskellä). Kieliopillisesta näkökulmasta sulkeisen skaalan astemääritteiden laajakäyttöisyyttä tukee se, että ne sopivat adpositiorakenteissa yhteen niin genetiivi- kuin partitiivitäydennyksenkin kanssa.

Avoimen skaalan astemääritteiden (melko, hyvin, erittäin) käyttöpotentiaali grammien yhteydessä on suppeampi. Tämä johtuu osin enemmän kieliopillisista ja osin puhtaasti semanttisista syistä. Kieliopilliselta kannalta nämä astemääritteet edellyttävät adpositiorakenteessa yleensä partitiivitäydennystä, joka mahdollistaa astemääritteen sijainnin välittömästi grammin edellä: erittäin lähellä kirkkoa tai kirkkoa erittäin lähellä vs. ${ }^{*}$ erittäin kirkon lähellä (mutta myös * erittäin kirkkoa lähellä).

Astemääritteen ja grammin vierekkäisen sijainnin salliva partitiivirakennekaan ei silti mahdollista avoimen asteikon määritteitä, jos grammin semantiikka ei tue tätä. Esimerkiksi * erittäin kohti kirkkoa on epäkieliopillinen ilmeisesti siksi, että kohti ilmaisee niin vahvasti rajallista skalaarisuutta, että avoimen asteikon astemääritteet eivät luontevasti sovi sen yhteyteen. Rajoina toimivat tällöin yhtäältä kontaktisektori, joka rajaa hakualueen, ja toisaalta ideaalivektori, jonka kanssa yhteen lankeava toteutumavektori edustaa relaation maksimaalista astetta. Toteutumavektori, joka jää niukasti kontaktisektorin ulkopuolelle, voidaan ilmaista approksimatiivisen melkein-astemääritteen avulla (melkein kohti). Muuten mikä tahansa toteutumavektori, joka sisältyy kontaktisektoriin, toteuttaa relaation samanarvoisesti muiden vastaavien vektorien kanssa. Kontaktisektorin sisällä ei toisin sanoen erotu sellaisia aste-eroja, joita voisivat ilmaista ${ }^{*}$ melko kohti kirkkoa ja * erittäin kohti kirkkoa. Ylipäätään näyttää siltä, että avoimen skaalan astemääritteet eivät sovi yhteen suuntaa ilmaisevien grammien kanssa.

Astemääritteiden käytön näkökulmasta omalaatuisia ovat grammien komparatiivimuodot (lähempänä, kauempana, keskemmällä). Ne kelpuuttavat määritteikseen kvanttoriadverbeja sekä etäisyyden ilmauksia, joiden käyttö grammien kanssa on muuten hyvin rajallista: vähän $\sim$ paljon reilusti kaksi metriä keskemmällä; vähän paljon reilusti kaksi metriä lähempänä (peruskiintopistettä kuin vertailukiintopiste). Komparatiivimuotojen yhteydessä näillä ilmaistaan muuttujan etäisyyttä nimenomaan vertailukiintopisteestä eikä peruskiintopisteestä. Avoimen skaalan astemääritteet sitä vastoin ovat selvästi epäkieliopillisia komparatiivimuotojen määritteinä: *erittäin lähempänä ja *hyvin keskemmällä.

Astemääritteiden joukossa erikoislaatuisia ovat myös tässä tutkimuksessa avoimen skaalan ilmauksiin lukemani pientä määrää ilmaisevat lieventimet vähän, hieman ja hiukan. Vaikka niitä voi pitää avoimen skaalan astemääritteinä (vähän ruma, hiukan ikävä; ks. ISK \$ 615), niiden käyttöala poikkeaa sekä muista avoimen skaalan astemääritteistä (melko, erittäin) että varsinaisista kvanttoriadverbeista (paljon, runsaasti). Grammeihin liittyessään ne toimivat joissain yhteyksissä muiden kvanttoriadverbien kaltaisesti, toisinaan taas muiden avoimen skaalan astemääritteiden tapaan. Esimerkiksi grammien komparatiivimuotoja ne voivat määrittää muiden kvanttoriadverbien rinnalla, vaikka 
komparatiivimuodot torjuvatkin varsinaiset avoimen skaalan astemääritteet: Seisoin Heikkiä vähän paljon reippaasti *melko *erittäin lähempänä ovea. Perusmuotoista lähellä-grammia määrittäessään ne taas ryhmittyvät muiden avoimen skaalan astemääritteiden kanssa, mutta varsinaiset kvanttoriadverbit torjutaan: Seisoin vähän melko erittäin $\sim^{\star}$ paljon $\sim{ }^{\star}$ reippaasti lähellä Heikkiä.

Varsinaiset kvanttoriadverbit kuten paljon tai runsaasti sopivat parhaiten sellaisiin grammirakenteisiin, joissa on mukana vertailukiintopiste. Tällaisia ovat ennen kaikkea grammien komparatiivimuodot. Vaikka ${ }^{\star}$ paljon lähellä, ${ }^{\star}$ paljon kaukana ja ${ }^{\star}$ paljon keskellä ovat kielenvastaisia, komparatiivimuodot paljon lähempänä, paljon kauempana ja paljon keskemmällä ovat hyväksyttäviä. Matkan tai etäisyyden ilmaukset puolestaan sopivat grammien niihin käyttöihin, joissa kuvataan joko kuljettua matkaa (Juoksin kaksisataa metriä koulua kohti) tai muuttujan ja (vertailu)kiintopisteen välistä etäisyyttä (Liisa asuu meitä 50 kilometriä lähempänä mummia; Tikka lensi 15 senttiä taulun ohi).

\section{Lopuksi}

Grammien ja astemääritteiden tarkastelu nostaa esiin uusia, tärkeitä eroja eri grammiryhmien välillä mutta myös samoihin semanttisin perustein rajattuihin grammiryhmiin kuuluvien yksittäisten grammien merkityksissä. Talmyn (2017) esittämä jako keskihakuisiin ja keskipakoisiin grammeihin saa samalla tässä kirjoituksessa esittämistäni havainnoista täsmennystä ja täydennystä. Läheskään aina skalaarisuus ei nimittäin perustu pelkkään muuttujan ja kiintopisteen väliseen etäisyyteen. Skalaarisuus voi perustua myös muuttujan etäisyyteen kohdennuspisteestä. Joskus se taas perustuu toteutumavektorin sekä kontaktisektorin ja ideaalivektorin suhteeseen. Siinä mielessä Talmyn erottama keskihakuisuuden ja keskipakoisuuden oppositio kuitenkin toteutuu kaikissa mainituissa suhteissa, että niissä on aina kyse (laajassa mielessä) joko kasvavasta läheisyydestä tai etäisyydestä. Esimerkiksi suuntagrammi kohti ei ole varsinaisesti keskihakuinen, sillä sen ilmaisemassa skalaarisuudessa muuttujan etäisyys kiintopisteestä ei ole olennainen asia. Silti kohti-grammin merkitys on keskihakuistyyppinen, koska siinä skalaarisuus kasvaa ideaalivektorin ja toteutumavektorin välisen poikkeaman pienetessä. Vastaavasti ohi on keskipakoisen tyyppinen suuntagrammi, sillä sen skalaarisuus kasvaa, kun toteutumavektorin poikkeama kontaktisektorista kasvaa.

Tässä kirjoituksessa olen tarkastellut skalaarisuuden näkökulmasta vain muutamaa spatiaalisten grammien keskeistä ryhmää. Tarkastelua voisi helposti laajentaa uusiin spatiaalisten grammien ryhmiin sekä muihin kuin spatiaalisiin grammeihin. Esimerkiksi temporaalisten grammien yhteydessä astemääritteillä on samankaltaisia tehtäviä kuin edellä on havaittu (vähän ennen joulua, ihan äsken, melko hiljattain; ajan adverbien semantiikasta ks. Sulkala 1981).

Astemääritteet nostavat grammeista esille merkityspiirteitä, jotka muuten jäisivät helposti havaitsematta. Grammien ja astemääritteiden yhteistarkastelu paljastaa samankaltaisuuksia myös grammien ja adjektiivien välillä. Laajemmassa mielessä astemääritteiden 
tarkastelu liittää grammien semantiikan aspektin ja kvantifikaation tapaisiin ilmiöihin, kuten Paradis (2001) korostaa. Suomessakin monet astemääritteet voivat toimia paitsi grammien myös kvanttoriadverbien ja -pronominien määritteinä: ihan vähän kahvia, varsin monet ihmiset, melko runsaasti rahaa. Astemääritteiden erilaisten tehtävien tarkastelu tarjoaa runsaasti kiinnostavia jatkotutkimuksen aiheita.

\section{Lähteet}

Duvallon, Outi 2019: Leksikaalistuneiden ja kiteytymättömien -kin-ilmausten suhteesta suomessa. Esitelmä. Suomalais-virolainen kielioppiseminaari Kielioppia lypsämässä, Tarton yliopisto, Viro 11.-13.4.2019.

Hakanen, Aimo 1973: Adjektiivien vastakohtasuhteet suomen kielessä. Suomalaisen Kirjallisuuden Seuran toimituksia 311. SKS, Helsinki.

Hamunen, Markus tulossa: Eräät suomen väylägrammit ajan liikemetaforissa. ANNı JÄÄskeläIneN (toim.): Ajassa kiinni: ajan kuvaamisen kieltä ja kielioppia. Gaudeamus, Helsinki.

Hamunen, Markus - Huumo, Tuomas tulossa: Kielitaju kielentutkijan työkaluna. - Milla Luodonpä̈̈-Manni, Markus Hamunen, Reetta Konstenius, Matti Miestamo, Urpo Nikanne ja KAIUS SinNemäKI (toim.): Kielentutkimuksen metodologian käsikirja.

Haukioja, Timo 1998: Rektio ja rajattuus. Huomioita suomen adpositioiden rektiosta. AnNeli PajuneN (toim.): Kieliopillistumisesta, analogiasta ja typologiasta, 217-229. SKS, Helsinki.

Huumo, Tuomas 2005: Kognition kieli: miten suomen kieli käsitteistää aistihavainnon? Sananjalka 47, 7-42.

2010: Suomen väyläadpositioiden prepositio- ja postpositiokäyttöjen merkityseroista. Virittäjä $114(4), 531-561$.

ISK = Hakulinen, Auli - Vilkuna, Maria - Korhonen, Rittta - Koivisto, Vesa - Heinonen, TARJA RittTa - AlHo, IrJa 2004: Iso suomen kielioppi. SKS, Helsinki.

Jantunen, Jarmo Harri 2004: Minulla on aivan paljon rahaa - Fraseologiset yksiköt suomen kielen opetuksessa. Virittäjä 113 (3), 356-381.

Kennedy, Christopher - McNally, Louise 2005: Scale structure, degree modification, and the semantics of gradable predicates. Language 81 (2), 345-381. https://doi.org/10.1353/lan.2005.0071

Langacker, Ronald W. 1999: Grammar and conceptualization. Cognitive Linguistics Research 14. Mouton De Gruyter, Berlin.

2008: Cognitive Grammar. A basic introduction. Oxford University Press, New York.

LeHISMETS, KeRSTEN 2013: Yli, läpi ja kautta. Suomen grammirakenteiden voimadynamiikkaa. Virittäjä $117(3), 346-371$.

Lestrade, SANDer 2010: Finnish case alternating adpositions: A corpus study. Linguistics 48(3), 603628. https://doi.org/10.1515/ling.2010.019

Levinson, Stephen C. 2003: Space in language and cognition. Explorations in cognitive diversity. Cambridge University Press, Cambridge. https://doi.org/10.1017/CBO9780511613609

Levinson, Stephen C. - Meira, Sergio 2003: 'Natural Concepts' in the spatial topological domain Adpositional meanings in crosslinguistic perspective: An exercise in semantic typology. Language 79 (3), 485-516. https://doi.org/10.1353/lan.2003.0174

OjutKangas, Krista - Huumo, Tuomas 2010: Mikä erottaa muodot sisällä ja sisässä? "Synonyymisten" muotojen analyysi. Sananjalka 52, 19-45.

Orpana, TerTtu 1988: Kuvaus vai kommentti. Tutkimus suomen kielen adjektiviadverbien semanttisesta tulkinnasta. Opera Fennistica \& Linguistica 2. Tampereen yliopiston suomen kielen ja yleisen kielitieteen laitos, Tampere.

Paradis, Carita 1997: Degree modifiers of adjectives in spoken British English. Lund Studies in English 92. Lund University Press, Lund. 
Paradis, Carita 2001: Adjectives and boundedness. Cognitive Linguistics 12, 47-64. https://doi. org/10.1515/cogl.12.1.47

Posio, IlkKa 2019: Sanojen niin, näin ja noin monifunktioisuus. Pro gradu -tutkielma. Suomen kieli ja suomalais-ugrilainen kielentutkimus. Turun yliopisto, Turku.

RAdDen, GÜNTER - Dirven, René 2007: Cognitive English grammar. Cognitive Linguistics in practice 2. John Benjamins, Amsterdam. https://doi.org/10.1075/clip.2

SIVONen, JARI 2005: Mutkia matkassa. Nykysuomen epäsuoraa reittiä ilmaisevien verbien kognitiivista semantiikkaa. Suomalaisen Kirjallisuuden Seuran Toimituksia 1017. SKS, Helsinki.

SKS = Suomalaisen Kirjallisuuden Seura .

Sulkala, Helena 1981: Suomen kielen ajan adverbien semantiikkaa. Acta Universitatis Ouluensis. Series B Humaniora 8. Oulun yliopisto, Oulu.

Svorou, Soteria 1994: The grammar of space. Typological studies in language 25. John Benjamins, Amsterdam. https://doi.org/10.1075/tsl.25

TAlmy, LeOnard 2000: Toward a cognitive semantics. Vol. I: Concept structuring systems. MIT Press, Cambridge. https://doi.org/10.7551/mitpress/6847.001.0001

2005: The fundamental system of spatial schemas in language. Beate Hampe ja Joseph E. GRADY (toim.): From Perception to Meaning: Image Schemas in Cognitive Linguistics. De Gruyter Mouton, Berlin.

2017: The targeting system of language. MIT Press, Cambridge.

ZwARTs, JoosT 1997: Vectors as relative positions: A compositional semantics of modified PPs. Journal of Semantics 14, 57-86. https://doi.org/10.1093/jos/14.1.57

2005: Prepositional aspect and the algebra of paths. Linguistics and Philosophy 28, 739-779. https://doi.org/10.1007/s10988-005-2466-y

ZwARTs, JOOST - WINTER, YOAD 2000: Vector space semantics: A model-theoretic analysis of locative prepositions. Journal of Logic, Language, and Information 9 (2), 169-211. https://doi. org/10.1023/A:1008384416604

\section{Tuomas Huumo: What degree modifiers reveal about the meaning of Finnish spatial grams}

It has been observed (e.g. in the comprehensive grammar ISK 2004) that some Finnish spatial grams (adpositions or adverbs) allow for degree modifiers, while others do not. Degree modifiers commonly relate with adjectives or adverbs and express scalar meanings such as 'somewhat', 'very', 'extremely' (open-scale degree modifiers; cf. Paradis 2001; Kennedy \& McNally 2005), or 'almost', 'quite', 'completely', (closedscale degree modifiers). Talmy $(2017,315-316)$ discusses the uses of degree modifiers with English scalar prepositions and draws a further distinction between centripetal and centrifugal adpositions. With centripetal adpositions, such as near, the degree increases the closer the Figure (the entity to be located) is to the Ground (the entity with respect to which Figure is located). With centrifugal adpositions, such as above, the degree increases the further away the Figure is from the Ground.

In this article I analyse uses of open-scale and closed-scale degree modifiers with Finnish spatial grams, that is, multi-functional grammatical words (in the sense of Svorou 1994), which can be used as adpositions or adverbs. One example of a centripetal Finnish adposition is lähellä 'near/close (to)', which is compatible with both open-scale and closed-scale degree modifiers. The conceived nature of the scale as open or closed depends on the case marking of the Ground, which is grammatically expressed as the complement of the apdosition. Open-scale modifiers are only felicitous if the Ground is in the partitive 
(e.g., hyvin lähe-llä kirkko-a [very near church-PARTITIVE] 'very close to the church') but not with a genitive Ground ( ${ }^{\star}$ hyvin kirko- $n$ [GENITIVE] lähe-llä). The genitive Ground only allows for closed-scale modifiers such as ihan 'quite', which are also felicitous with the partitive Ground (ihan kirko- $n$ [GeNitive] lähe-llä and ihan lähe-llä kirkko-a [PARTITIVE], both meaning 'quite close to the church'). This demonstrates that the case marking of the Ground sometimes correlates with the conceptualization of the scale as open versus closed.

I analyse the compatibility of degree modifiers with three groups of Finnish spatial grams: 1) topological grams (e.g. lähellä 'near/close (to)' and luona 'at'), 2) directional grams (kohti 'towards', ohi 'past'), and 3) specifying grams (keskellä 'in the middle of'). I show that in group 1, the scale relates to the distance between Figure and Ground, reflecting Talmy's opposition between centripetal and centrifugal meanings. In group 2, the scale relates to the direction of a vector that starts from a moving or oriented Figure and relates to the Figure's orientation with the Ground, i.e. whether the Figure, if moving in the direction of the vector, would end up in contact with the Ground or not. The scale expressed is bounded and measures how directly the vector points towards the Ground. The highest degree is reached by a vector that points exactly to the midpoint of the Ground. The grams in group 3 focus on a targeting point and express a bounded type of centripetal scalarity that reaches its highest degree when the Figure is located exactly at the targeting point (consider, for instance, a pole standing 'exactly in the middle of' a field).

Tuomas Huumo

thuumo@utu.fi

Suomen kieli ja suomalais-ugrilainen kielentutkimus

20014 Turun yliopisto 